\title{
Growth and gas formation by Lactobacillus wasatchensis, a novel obligatory heterofermentative nonstarter lactic acid bacterium, in Cheddar-style cheese made using a Streptococcus thermophilus starter ${ }^{1}$
}

\author{
Fatih Ortakci, ${ }^{*}$ Jeffery R. Broadbent, ${ }^{* 2}$ Craig J. Oberg, ${ }^{*} \dagger$ and Donald J. McMahon ${ }^{* 2}$ \\ *Western Dairy Center, Department of Nutrition, Dietetics, and Food Sciences, Utah State University, Logan 84322-8700 \\ †Microbiology Department, Weber State University, Ogden, UT 84408-2506
}

\begin{abstract}
A novel slow-growing, obligatory heterofermentative, nonstarter lactic acid bacterium (NSLAB), Lactobacillus wasatchensis WDC04, was studied for growth and gas production in Cheddar-style cheese made using Streptococcus thermophilus as the starter culture. Cheesemaking trials were conducted using $S$. thermophilus alone or in combination with $L b$. wasatchensis deliberately added to cheese milk at a level of $\sim 10^{4} \mathrm{cfu} /$ $\mathrm{mL}$. Resulting cheeses were ripened at 6 or $12^{\circ} \mathrm{C}$. At d 1 , starter streptococcal numbers were similar in both cheeses $\left(\sim 10^{9} \mathrm{cfu} / \mathrm{g}\right)$ and fast-growing NSLAB lactobacilli counts were below detectable levels $\left(<10^{2} \mathrm{cfu} / \mathrm{g}\right)$. As expected, Lactobacillus wasatchensis counts were 3 $\times 10^{5} \mathrm{cfu} / \mathrm{g}$ in cheeses inoculated with this bacterium and below enumeration limits in the control cheese. Starter streptococci decreased over time at both storage temperatures but declined more rapidly at $12^{\circ} \mathrm{C}$, especially in cheese also containing $L b$. wasatchensis. Populations of fast-growing NSLAB and the slowgrowing $L b$. wasatchensis reached $5 \times 10^{7}$ and $2 \times$ $10^{8} \mathrm{cfu} / \mathrm{g}$, respectively, after $16 \mathrm{wk}$ of storage at $12^{\circ} \mathrm{C}$. Growth of NSLAB coincided with a reduction in galactose concentration in the cheese from 0.6 to $0.1 \%$. Levels of galactose at $6^{\circ} \mathrm{C}$ had similar decrease. Gas formation and textural defects were only observed in cheese with added $L b$. wasatchensis ripened at $12^{\circ} \mathrm{C}$. Use of $S$. thermophilus as starter culture resulted in galactose accumulation that $L b$. wasatchensis can use to produce $\mathrm{CO}_{2}$, which contributes to late gas blowing
\end{abstract}

\footnotetext{
Received March 10, 2015.

Accepted July 14, 2015.

${ }^{1}$ In a previous paper (Ortakci et al., 2015) this bacteria was called Lactobacillus wasatchii. The accepted name is Lactobacillus wasatchensis (Oberg et al., 2015), in homage to the Wasatch mountain range running between Weber State University and Utah State University where this bacterium was first isolated and characterized.

${ }^{2}$ Corresponding authors: Donald.McMahon@usu.edu and Jeff. Broadbent@usu.edu
}

in Cheddar-style cheeses, especially when the cheese is ripened at elevated temperature.

Key words: cheese, late blowing, nonstarter lactic acid bacteria, Streptococcus thermophilus, galactose

\section{INTRODUCTION}

The manufacture of Cheddar cheese is characterized by use of mesophilic Lactococcus lactis starter strains and moderate cook temperatures $\left(\sim 39^{\circ} \mathrm{C}\right.$; Michel and Martley, 2001). However, the short method for Cheddar cheese manufacture (Bley et al., 1985) uses thermophilic Streptococcus thermophilus along with the regular mesophilic Lc. lactis ssp. lactis or cremoris starter culture so that rapid acid production continues even at cook temperatures of 42 to $43^{\circ} \mathrm{C}$ (Michel and Martley, 2001). Two advantages to using the short method include reduced manufacturing costs and a lower risk of bacteriophage infection (Cogan, 2011).

Unfortunately, this type of manufacturing process has also been linked to accumulation of up to 33 $\mathrm{mmol} / \mathrm{kg}$ of galactose in cheese $(\sim 0.6 \% \mathrm{wt} / \mathrm{wt})$ and to unwanted $\mathrm{CO}_{2}$ production by nonstarter lactic acid bacteria (NSLAB). This can lead to development of slits and fractures in the aging cheese (Tinson et al., 1982b; Michel and Martley, 2001). Galactose accumulates because only the glucose moiety of lactose is used by $S$. thermophilus, thus galactose is excreted back into the milk or cheese as part of a Lac S-mediated antiport system for lactose uptake (Tinson et al., 1982a; Hutkins and Ponne, 1991; Vaillancourt et al., 2004). Heterofermentative NSLAB are known to use residual galactose to produce $\mathrm{CO}_{2}$, leading to gassy defect in Cheddar cheese (Radford and Hull, 1982; Tinson et al., $1982 \mathrm{~b})$ that results in economic losses to the cheese manufacturer (Golnazarian, 2001).

We recently reported that Lactobacillus wasatchensis WDC04 - a slow-growing, obligatory heterofermentative (OHF) NSLAB of cheese (Oberg et al., 2015) can use galactose and produce gas in broth (Ortakci et al., 2015a) and in cheese (Ortakci et al., 2015b). When 
this NSLAB is present in high numbers in aging cheese it promotes gas production via fermentation of galactose (or other hexoses; Ortakci et al., 2015b). Based on these observations, we hypothesized that growth and gas production by $L b$. wasatchensis would be promoted if $S$. thermophilus was included as part of a Cheddar cheese starter culture because the cheese would contain higher levels of residual galactose. We have also shown that $L b$. wasatchensis readily grows on cell lysate material (presumably from the ribose that is released) so that starter culture lysis during cheese storage also promotes growth of $L b$. wasatchensis. To confirm these findings, we inoculated milk with $L b$. wasatchensis and then used $S$. thermophilus as a starter culture to make Cheddar-style cheese. Microbial populations, including starter culture, fast-growing NSLAB (which in our creamery is predominantly Lactobacillus curvatus), and the slow-growing NSLAB $L b$. wasatchensis were then enumerated, along with measurements to determine the extent of gas formation, through 23 wk of cheese storage at 6 and $12^{\circ} \mathrm{C}$.

\section{MATERIALS AND METHODS}

\section{Bacterium and Growth}

Working cultures of $L b$. wasatchensis WDC04 were prepared from frozen stocks stored at $-80^{\circ} \mathrm{C}$ by sequential transfer twice into de Man, Rogosa and Sharpe (MRS; Becton Dickinson Inc., Sparks, MD) broth containing $1.5 \%$ (wt/vol) ribose (donated by Bioenergy Life Science Inc., Ham Lake, MN; MRS+R). Cultures were incubated anaerobically using GasPak EZ (Becton Dickinson Inc.) at $23^{\circ} \mathrm{C}$ for $40 \mathrm{~h}$. Cells for the cheesemaking experiments were propagated in $400 \mathrm{~mL}$ of MRS $+\mathrm{R}$ for $40 \mathrm{~h}$ at $23^{\circ} \mathrm{C}$. Cells were harvested by centrifugation at $7,500 \times g$ for $10 \mathrm{~min}$ at $4^{\circ} \mathrm{C}$, washed twice with sterile $0.1 \%$ (wt/vol) peptone water, and harvested after each wash. The cell suspensions were used in the cheesemaking trials. Cell suspension concentrations were determined by spread plate counts on $\mathrm{MRS}+\mathrm{R}$ agar incubated anaerobically for $5 \mathrm{~d}$ at $23^{\circ} \mathrm{C}$.

\section{Cheesemaking}

Fresh bovine milk was obtained from the George B. Caine Dairy Research and Teaching Center (Wellsville, UT) and transported to the Aggie Creamery at Utah State University (Logan, UT). The milk was standardized to a protein-to-fat ratio of 0.84 , pasteurized at $73^{\circ} \mathrm{C}$ for $15 \mathrm{~s}$, and $136 \mathrm{~kg}$ was added into an open stainless steel vat (each vat had previously been cleaned then heat sanitized for $30 \mathrm{~min}$ ). All vats of milk were warmed to $31^{\circ} \mathrm{C}$, and then $0.25 \mathrm{~g} / \mathrm{kg}$ of frozen pellets containing S. thermophilus M6 starter culture (Chr. Hansen Inc., Milwaukee, WI) were added. For the experimental vats, $\sim 10^{4} \mathrm{cfu} / \mathrm{mL}$ of $L b$. wasatchensis was also added and the milk allowed to ripen for $10 \mathrm{~min}$. Then, $0.12 \mathrm{~mL} / \mathrm{kg}$ of a $32 \%$ (wt/wt) $\mathrm{CaCl}_{2}$ solution (Nelson-Jameson Inc., Marshfield, WI), $0.13 \mathrm{~mL} / \mathrm{kg}$ of annatto, and $0.16 \mathrm{~mL} /$ $\mathrm{kg}$ of double-strength ( 650 international milk clotting units/mL) chymosin rennet (Maxiren; DSM Food Specialties USA Inc., Eagleville, PA) were added and the milk allowed to set undisturbed for $20 \mathrm{~min}$. After cutting and healing, the curd and whey mixtures were stirred for $10 \mathrm{~min}$, heated to $39^{\circ} \mathrm{C}$ over $35 \mathrm{~min}$, and then stirred for another $10 \mathrm{~min}$. Curd was stirred until a curd $\mathrm{pH}$ of 6.3 was reached with partial whey drainage. Remaining whey was then drained and curd was allowed to mat together, cut into slabs, and cheddared until the curd $\mathrm{pH}$ reached 5.25. Curd was milled and salted $(30 \mathrm{~g} / \mathrm{kg}$ of curd) in 3 applications with $5 \mathrm{~min}$ between each application. Salted curd from each vat was separated into two $7-\mathrm{kg}$ portions and placed into open plastic containers. Curd was packed into plastic hoops and pressed overnight $\left(140 \mathrm{kPa}, \sim 18 \mathrm{~h}, \sim 20^{\circ} \mathrm{C}\right)$. The cheese was then dehooped and each block cut into 10 pieces of $\sim 600 \mathrm{~g}$; each piece was vacuum packaged. Five pieces were stored at $6^{\circ} \mathrm{C}$ and 5 at $12^{\circ} \mathrm{C}$. Control cheeses were made using the same procedure except that no $L b$. wasatchensis was added. Cheesemaking was conducted in triplicate.

\section{Microbial Enumerations}

At $0,8,16$, and $23 \mathrm{wk}$, cheese samples (11 g) were collected from the interior of each cheese and homogenized in $99 \mathrm{~mL}$ of sterilized $2 \%$ (wt/vol) sodium citrate (previously warmed to $45^{\circ} \mathrm{C}$ ) using a Stomacher 400 Circulatory laboratory blender (Seward Laboratory Systems Inc., Bohemia, NY) set for $3 \mathrm{~min}$ at $230 \mathrm{rpm}$ (Broadbent et al., 2013). Serial dilutions were prepared in $0.1 \%$ sterile peptone water. In this experiment, the lowest dilution used for bacterial enumeration was $10^{-2}$. For calculating mean numbers and when making plots of microbial numbers, a value of $5 \times 10^{1} \mathrm{cfu} / \mathrm{g}$ was used for samples with counts $<10^{2} \mathrm{cfu} / \mathrm{g}$.

Streptococcus thermophilus. Streptococcus thermophilus was enumerated as described by Tabasco et al. (2007) using M17 agar (Becton Dickinson Inc.) containing 1\% (wt/vol) lactose (Sigma-Aldrich Inc., St. Louis, MO) incubated aerobically at $45^{\circ} \mathrm{C}$ for $24 \mathrm{~h}$.

Fast-Growing NSLAB. The method of Oberg et al. (2011) for enumerating NSLAB on MRS agar supplemented with $2 \mu \mathrm{g} / \mathrm{mL}$ of vancomycin incubated anaerobically at $37^{\circ} \mathrm{C}$ for $48 \mathrm{~h}$ was used to enumerate 
fast-growing NSLAB. These NSLAB counts were designated as NSLAB37 and do not include $L b$. wasatchensis, as it requires ribose for growth and even with ribose does not grow quickly enough to be enumerated in $48 \mathrm{~h}$. Lactobacillus wasatchensis is resistant to vancomycin, as is $L b$. curvatus, but grow more slowly and will not form observable colonies on MRS-vancomycin within $48 \mathrm{~h}$ (Ortakci et al., 2015b).

A crossover time for when NSLAB37 numbers equaled and then surpassed starter numbers was determined for each cheese. The mean log numbers from 3 reps were plotted against storage time and a trend line was fitted to each set of data based on the highest correlation coefficient obtained. The time (in weeks) when the lines intersect was designated the crossover time (Oberg et al., 2011). All plate counts were performed in duplicate using the spread plate method.

Lactobacillus wasatchensis. Nonstarter lactic acid bacteria were also enumerated on MRS-vancomycin agar supplemented with $1.5 \%$ ribose after $48 \mathrm{~h}$ of anaerobic incubations at $23^{\circ} \mathrm{C}$ and these counts were designated as NSLAB23. After obtaining counts for NSLAB23 and marking all the colonies $(\sim 1.5 \mathrm{~mm}$ in diameter) the plates were further incubated anaerobically at $23^{\circ} \mathrm{C}$ for an additional $72 \mathrm{~h}$. By this time, $L b$. wasatchensis formed observable colonies $(\sim 1 \mathrm{~mm}$ in diameter), which enabled differential enumeration of this organism from the fast-growing NSLAB23 colonies (Ortakci et al., 2015b).

\section{Relative Gas Measurements}

Gas production during cheese storage was measured by determining the extent of loosening of the plastic bag around the cheese block (Ortakci et al., 2015b). After pressing, similar-sized ( $\sim 600 \mathrm{~g})$ blocks of cheese were inserted into plastic bags (QME355 3.5 mil; Vilutis and Co. Inc., Frankfurt, IL) and the bag was vacuumsealed $\sim 5 \mathrm{~cm}$ from the cheese block. Vacuum-packaged cheese was then visually examined and, on the side of the package that had just been sealed, a line was drawn along the plastic bag at the position where it was pulled tightly against the cheese (d-0 line). After 8, 16, and $23 \mathrm{wk}$, the cheeses were examined for gas production, which was manifest by a loosening of the package. If the plastic bag was no longer tightly held against the cheese, the plastic bag was pulled away from the cheese block (on the same side where it was initially marked) as much as possible. A line was then drawn on the plastic bag at the point at which the 2 layers of the bag were still held together by any residual vacuum inside the bag. The distance between that line and the d-0 line was then measured and used as a relative measure of gas formation. The more gas produced, the further the plastic bag could be pulled away from the cheese block. When sufficient gas production had occurred inside the cheese package so that there was no longer any residual vacuum (compared with atmospheric pressure), the seal line of the cheese package could be pulled the full $5 \mathrm{~cm}$ from the cheese. The distance the package could be pulled was calculated in relation to this maximum distance and expressed as relative gas production. All cheeses were tested for relative gas production before opening the packs and sampling the cheese for microbial analysis. Therefore, for each treatment, 4 cheese packages were tested for relative gas production at 8 wk, 3 at 16 wk, and 2 at 23 wk.

\section{Chemical Analysis}

Proximate composition of the cheeses was determined after approximately $3 \mathrm{~d}$. Moisture content was measured by weight loss using $\sim 4 \mathrm{~g}$ of grated cheese in a microwave moisture analyzer (model SMART System 5; CEM Corporation, Matthews, NC) at $100 \%$ power with an endpoint setting of $<0.4 \mathrm{mg}$ of weight change over 2 s. Fat content was measured by a modified Babcock method (Wehr and Frank, 2004). Salt was measured by homogenizing grated cheese with distilled water for $4 \mathrm{~min}$ at $260 \mathrm{rpm}$ in a Stomacher. The resulting slurry was filtered through a Whatman \#1 filter paper and the filtrate was analyzed using a chloride analyzer (model 926, Corning, Medfield, MA). Salt-in-moisture (S/M) content was calculated as salt/(moisture + salt) and expressed as a percentage.

\section{Sugar and Organic Acid Analysis}

All cheese samples were analyzed by HPLC for lactose, galactose, lactic acid, and propionic acid at d 1 and after $16 \mathrm{wk}$ of storage as described by Phadungath (2011) and Ortakci et al. (2015b). About $5 \mathrm{~g}$ of cheese were manually homogenized for $90 \mathrm{~s}$ with $10 \mathrm{~mL}$ of $0.013 \mathrm{~N}$ sulfuric acid at $65^{\circ} \mathrm{C}$ then centrifuged at 7,000 $\times g$ for $10 \mathrm{~min}$ at $4^{\circ} \mathrm{C}$. The samples were held at $4^{\circ} \mathrm{C}$ for $20 \mathrm{~min}$ to solidify the fat layer and the supernatant was filtered then poured into a $0.5-\mathrm{mL}$ Microcon (Millipore Corporation, Bedford, MA) centrifugal filter device with a molecular weight cut-off of 3,000 Da and microcentrifuged at $14,000 \times g$ for $20 \mathrm{~min}$ at $4^{\circ} \mathrm{C}$ to remove soluble peptides. The filtrate was injected into the HPLC system containing a cation $\mathrm{H}^{+}$microguard cartridge (Bio-Rad Laboratories, Hercules, CA) and Rezex ROA-organic acid $\mathrm{H}^{+}$column $(300 \times 7 \mathrm{~mm}, 8$ $\mu \mathrm{m}$, Phenomenex, Torrance, CA) and held at $65^{\circ} \mathrm{C}$. Separation was performed isocratically using $0.013 \mathrm{~N}$ 
sulfuric acid as the mobile phase with quantification of analytes based on the external standard method described by Upreti et al. (2006a).

\section{Experimental Design}

The experiment was conducted as a randomized block with split-split plot design. Each pressed block was cut into $\sim 600$-g pieces, individually vacuum packaged, and randomly assigned to be stored at either 6 or $12^{\circ} \mathrm{C}$ for various time periods. Statistical analysis was performed using PROC GLIMMIX in SAS (version 9.1; SAS Institute Inc., Cary, NC) with addition of $L b$. wasatchensis as the main plot effect, storage temperature as a split plot effect, and storage time as a split-split plot effect. Significance was declared at $P<$ 0.05. Differences between means were determined using Tukey least squares means.

\section{RESULTS AND DISCUSSION}

\section{Initial Composition}

Significant differences were found in composition between control and Lb. wasatchensis-supplemented cheeses $(P<0.05)$. Higher moisture $(41.5 \%)$ and lower S/M (4.1\%) levels were observed in cheese made with added $L b$. wasatchensis $(P<0.05$; Table 1$)$. However, salt, $\mathrm{pH}$, and fat levels were the same in both cheeses $(P>0.05)$. This effect of adding $L b$. wasatchensis was unexpected. In previous work, when Cheddar cheese was made in a similar manner using Lactococcus lactis as the starter, adding $L b$. wasatchensis had no effect on cheese moisture content (Ortakci et al., 2015b). The set-to-salt time for the cheese was slightly longer (an additional $15 \mathrm{~min}$ ) when $L b$. wasatchensis was added, but this would not cause an increase in moisture content. In a similar manner, cheese made with lactococcal starter and containing added $L b$. wasatchensis took

Table 1. Mean $( \pm \mathrm{SE})$ composition of Cheddar-style cheese (at d 3) made using Streptococcus thermophilus with (LBW+) or without Lactobacillus wasatchensis (control) added at $10^{4} \mathrm{cfu} / \mathrm{mL}$ in milk

\begin{tabular}{lcc}
\hline Item & Control & LBW + \\
\hline Moisture & $38.8^{\mathrm{a}}(0.26)$ & $41.5^{\mathrm{b}}(0.16)$ \\
Salt & $1.93^{\mathrm{a}}(0.08)$ & $1.78^{\mathrm{a}}(0.03)$ \\
$\mathrm{S} / \mathrm{M}^{1}$ & $4.73^{\mathrm{a}}(0.18)$ & $4.11^{\mathrm{b}}(0.08)$ \\
$\mathrm{pH}$ & $5.27^{\mathrm{a}}(0.003)$ & $5.31^{\mathrm{a}}(0.01)$ \\
Fat & $30.7^{\mathrm{a}}(0.17)$ & $30.5^{\mathrm{a}}(0.00)$ \\
\hline
\end{tabular}

${ }^{\mathrm{a}, \mathrm{b}}$ Means with same letter within each row were not significantly different, $\alpha=0.05$.

${ }^{1} \mathrm{~S} / \mathrm{M}=$ salt-in-moisture. longer compared with making control cheese where no Lb. wasatchensis was added (Ortakci et al., 2015b).

Although S/M was lower in cheese with added $L b$. wasatchensis, it was still within the $\mathrm{S} / \mathrm{M}$ range reported by Agarwal et al. (2011) for Cheddar cheese made in the Unites States. The moisture content of the cheeses being at or above the legal maximum for Cheddar cheese was probably the result of the faster acidification rate ( 195 min set-to-salt time) that occurred when using $S$. thermophilus as the starter culture rather than $L c$. lactis.

\section{Starter Streptococci and NSLAB During Storage}

Starter S. thermophilus numbers in the cheese were influenced by both storage time and temperature, and an $L b$. wasatchensis $\times$ storage time interaction was observed $(P<0.05$; Table 2$)$. Differences in streptococcal numbers based on addition of $L b$. wasatchensis only occurred during storage at $12^{\circ} \mathrm{C}$ (Figure $1 \mathrm{~A}$ ). At $6^{\circ} \mathrm{C}$ starter numbers decreased $\sim 1.5-\log \mathrm{cfu} / \mathrm{g}$ after $23 \mathrm{wk}$ for all cheeses (Figure 1B), but at $12^{\circ} \mathrm{C}$ a greater reduction in starter numbers $(P<0.05)$ was noted in cheese with added $L b$. wasatchensis. Similar results were also observed in previous work with Cheddar cheese made using lactococcal starters (Ortakci et al., 2015b). The basis for this effect is unclear, as no obvious antimicrobial encoding gene(s) were found in the genome of $L b$. wasatchensis (F. Ortakci, unpublished data)

Nonstarter lactic acid bacteria numbers increased from undetectable levels $\left(<10^{2} \mathrm{cfu} / \mathrm{g}\right)$ to $10^{8}$ and $\sim 10^{7}$ $\mathrm{cfu} / \mathrm{g}$ for NSLAB23 and NSLAB37, respectively, after 23 wk storage (Figures 1,2). Within each replicate, levels and patterns of growth of NSLAB were similar, which was expected, as the salted curd from each replicate was divided into separate portions for storage, so the cheeses would be expected to have the same initial microbial background population.

Table 2. Analysis of variance $P$-values for starter streptococcal numbers and gas production based on addition of Lactobacillus wasatchensis (LBW) during manufacture of Cheddar-style cheese and subsequent storage at 6 and $12^{\circ} \mathrm{C}$ for $23 \mathrm{wk}$

\begin{tabular}{lcrr}
\hline & & \multicolumn{2}{c}{$P$-value } \\
\cline { 3 - 4 } Source of Variation & df & Starter & Gas \\
\hline LBW & 1 & 0.3256 & 0.0146 \\
Temperature & 1 & 0.0239 & 0.0012 \\
LBW $\times$ temperature & 1 & 0.0383 & 0.0012 \\
Time & 3 & $<0.0001$ & $<0.0001$ \\
LBW $\times$ time & 3 & 0.5184 & $<0.0001$ \\
Temperature $\times$ time & 3 & 0.0964 & $<0.0001$ \\
\hline
\end{tabular}


No significant differences in either NSLAB number (i.e., NSLAB23 or NSLAB37) were observed in the cheese as a function of storage temperature or addition of $L b$. wasatchensis $(P>0.05)$. The absence of a temperature effect was unexpected, as prior studies usually report higher NSLAB counts at elevated storage temperatures (Peterson and Marshall, 1990; Fox et al., 1998; Ortakci et al., 2015b). Similar numbers of NSLAB at both storage temperatures in our study could be due to the availability of galactose as a readily available energy source. Facultative heterofermentative NSLAB, such as Lactobacillus curvatus - the predominant NSLAB found in Cheddar cheese manufactured at the Utah State University creamery (Broadbent et al., 2013) - gained a net of 2 moles of ATP via the Embden-Meyerhof pathway per mole of galactose or other hexose consumed (Axelsson, 2004). Thus, free galactose could provide sufficient energy for NSLAB to
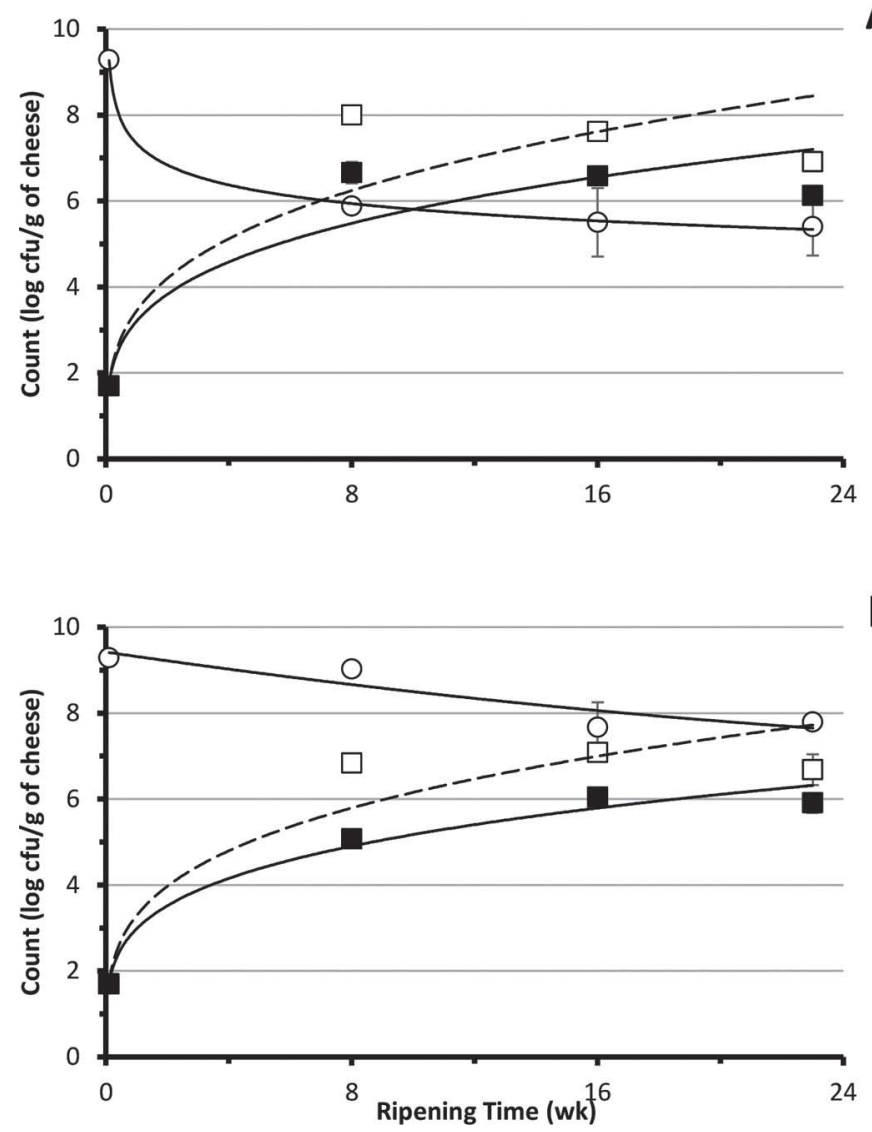

Figure 1. Mean numbers and best fit trendlines for Streptococcus thermophilus $(\bigcirc)$ and nonstarter lactic acid bacteria enumerated at 23 ( $\square$, dashed line) or $37^{\circ} \mathrm{C}$ ( $\square$, solid line) in Cheddar-style cheese made from milk to which had been added $10^{4} \mathrm{cfu} / \mathrm{mL}$ of Lactobacillus wasatchensis for cheese stored at either $12(\mathrm{~A})$ or $6^{\circ} \mathrm{C}(\mathrm{B})$; bars $=\mathrm{SE}$ $(\mathrm{n}=3)$.
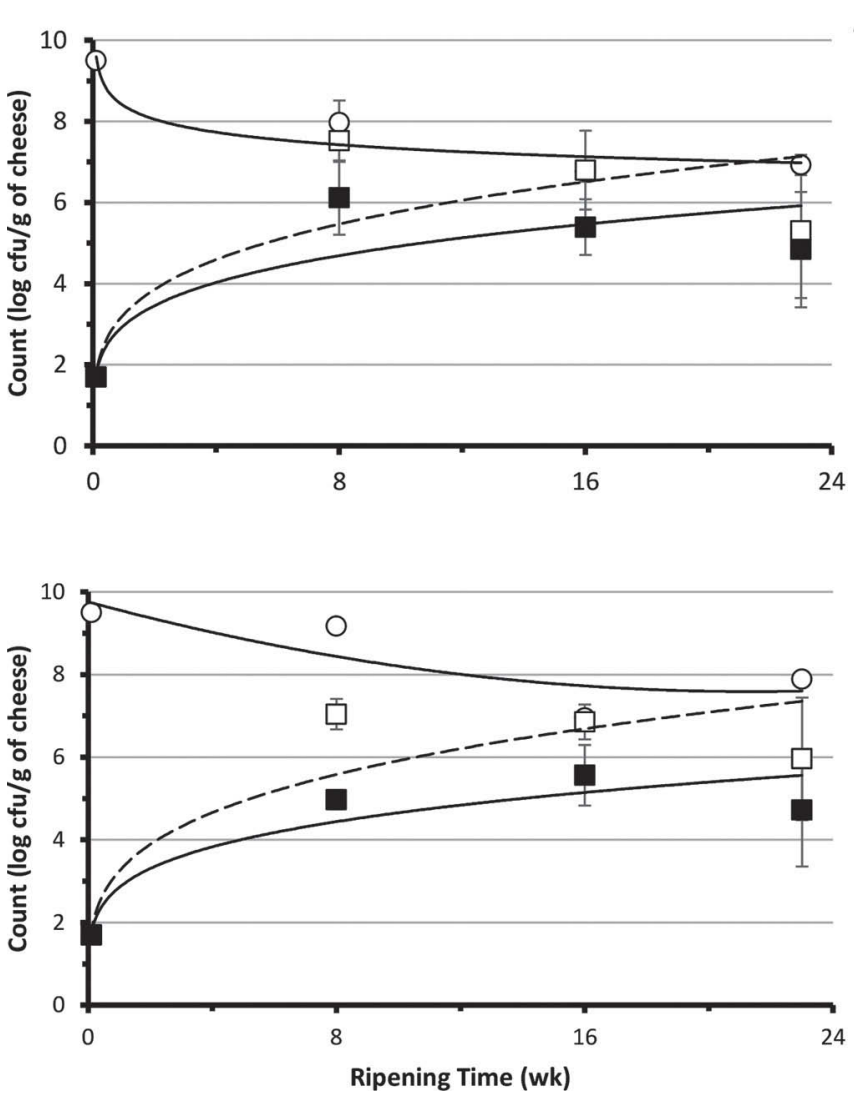

Figure 2. Mean numbers and best fit trendlines for Streptococcus thermophilus $(\bigcirc)$, nonstarter lactic acid bacteria enumerated at $23^{\circ} \mathrm{C}$ $\left(\square\right.$, dashed line), or nonstarter lactic acid bacteria enumerated at $37^{\circ} \mathrm{C}$ (ם, solid line) in control cheese stored at $12(\mathrm{~A})$ or $6^{\circ} \mathrm{C}(\mathrm{B})$; bars $=$ SE $(\mathrm{n}=3)$.

reach high final cell densities following storage at both temperatures.

Similar to the previous work (Ortakci et al., 2015b), NSLAB23 counts were significantly higher than NSLAB37 counts during the 23 wk of cheese storage $(P<0.05$; Figures 1 and 2$)$. The most likely explanation for this difference is that a temperature of $37^{\circ} \mathrm{C}$ inhibits growth of some NSLAB, just as we observed when trying to enumerate $L b$. wasatchensis. Even though NSLAB counts were not influenced by the storage temperature of the cheese, differences in the crossover times were observed between storage at 6 and $12^{\circ} \mathrm{C}$. There were also differences in the crossover time depending on whether $L b$. wasatchensis had been added to the milk (Figures 1 and 2). Crossover occurred earlier in cheese with added Lb. wasatchensis (Figure 1), as a more rapid decrease occurred in $S$. thermophilus numbers. Crossover between starter streptococci and NSLAB numbers occurred during the first 8 to $10 \mathrm{wk}$ in cheeses with added $L b$. wasatchensis stored at $12^{\circ} \mathrm{C}$, 
but not until after $23 \mathrm{wk}$ for the control cheese (Figure 2 ). When stored at $6^{\circ} \mathrm{C}$, the NSLAB numbers never reached the same level as the starter because of the longer retention of viable starter streptococci.

\section{Sugar and Organic Acids}

Sugar and organic acid profiles of the cheeses were similar in both control and Lb. wasatchensis-added cheeses stored at either 6 or $12^{\circ} \mathrm{C}$. Lactose content of the cheese was $0.2 \%$ at $\mathrm{d} 1$ and similar levels were observed after 16 wk of storage. Persistence of lactose in Cheddar cheese during storage has been previously shown by Fox et al. (1998), who reported the continued presence of lactose after $36 \mathrm{wk}$ of storage. A substantial amount (0.6 to $0.7 \%)$ of galactose was observed in all cheeses at $\mathrm{d} 1$. Accumulation of galactose occurred because $S$. thermophilus uses only the glucose moiety of lactose to produce lactic acid and does not use the galactose moiety (Tinson et al., 1982a; Hutkins and Morris, 1987; Mora et al., 2002; Vaillancourt et al., 2004). Adding $L b$. wasatchensis to the cheese milk did not have an effect on initial galactose concentrations because $L b$. wasatchensis uses galactose only very slowly in the absence of ribose (Ortakci et al., 2015a). Galactose levels fell to 0.1 to $0.2 \%$ after 16 wk of storage in all cheeses, which can be attributed to the growth of $L b$. wasatchensis along with other NSLAB.

Initial lactic acid level in the cheeses $(\sim 1.0 \%)$ was lower than previously reported by McSweeney and Fox (2004) and McMahon et al. (2014), who both found 1.4 to $1.5 \%$ lactic acid in the cheese at $\mathrm{d} 1$. This may be related to using $S$. thermophilus as the starter culture whereas previous reports were for Cheddar cheese made using Lc. lactis starter cultures. Perhaps the relatively fast make time and the cheeses only having an initial $\mathrm{pH}$ in the range $\sim 5.2$ to 5.3 may account for the lower lactic acid concentrations in the cheeses. Lactic acid levels increased to $1.7 \%$ after $16 \mathrm{wk}$ in all cheeses at both storage temperatures. Assuming this was a function of NSLAB metabolism, this was not surprising, as all cheeses had similar NSLAB numbers after 16 wk. The slightly higher lactic acid levels after 16 wk of storage compared with our previous study (Ortakci et al., 2015b) could be because of the cheese having lower $\mathrm{S} / \mathrm{M}$ in the present study. Production of lactic acid during storage is influenced by S/M (Upreti et al., 2006b).

Propionic acid also increased in all cheeses during cheese storage. Levels of propionic acid increased from an initial 0.02 to $0.2 \%$ after 16 wk of storage. This occurred concomitantly with NSLAB counts reaching levels of $\geq 10^{6} \mathrm{cfu} / \mathrm{g}$, and NSLAB activity has been reported to increase propionic acid concentration in cheese during storage (St-Gelais et al., 1991; Bouzas et al., 1993; McMahon et al., 2014). Lactobacillus curvatus, which is the predominant NSLAB found in our cheese (Broadbent et al., 2013), does have the metabolic capability to produce propionic acid (J. R. Broadbent, unpublished data).

\section{Growth of $L b$. wasatchensis}

In the control cheese, we were unable to detect $L b$. wasatchensis because the enumeration method has a detection limit requiring $L b$. wasatchensis numbers to be within $1.5 \mathrm{log} \mathrm{cfu} / \mathrm{g}$ of the fast-growing NSLAB population (Ortakci et al., 2105b). As Lb. wasatchensis is a part of the NSLAB microbiota in our cheesemaking facility, it was probably present at numbers too low to detect by enumerating using the MRS-R-vancomycin plate count method. This presents a challenge for determining the cause of sporadic late gas blowing in Cheddar cheese, as slow-growing NSLAB such as $L b$. wasatchensis can be difficult to detect and enumerate if the NSLAB populations are high.

When $L b$. wasatchensis was added in sufficient numbers during cheese manufacture it could be easily enumerated and population growth observed during cheese storage, as shown in Figure 3. Temperature had a significant effect on growth of $L b$. wasatchensis during storage $(P<0.05)$. The greatest increase in $L b$. wasatchensis cell numbers occurred during the first 8 wk at either temperature. Higher counts were observed at the elevated storage temperature of $12^{\circ} \mathrm{C}$ compared with $6^{\circ} \mathrm{C}$. This corresponds with the rapid reduction in numbers of $S$. thermophilus at $12^{\circ} \mathrm{C}$ (Figure 3 ).

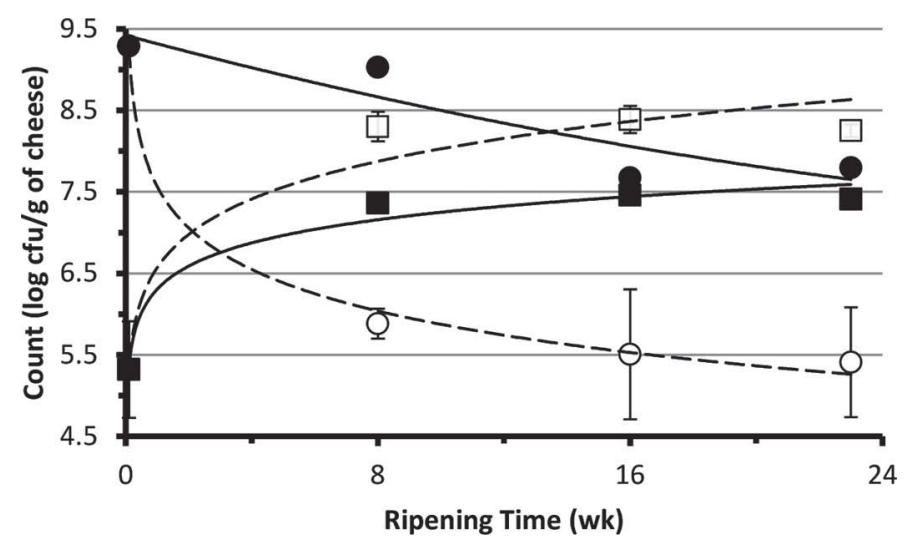

Figure 3. Comparison of concomitant increase in mean numbers of Lactobacillus wasatchensis (squares) and decrease in mean numbers of Streptococcus thermophilus (circles) in Cheddar-style cheese made from milk to which had been added $10^{4} \mathrm{cfu} / \mathrm{mL}$ of $L b$. wasatchensis and stored at $12^{\circ} \mathrm{C}$ (open symbols and dashed lines) or $6^{\circ} \mathrm{C}$ (solid symbols and lines); bars $=\mathrm{SE}(\mathrm{n}=3)$. 
Lactobacillus wasatchensis is capable of growing on carbohydrates released during the lysis of other bacteria (particularly starter culture bacteria), and can reach high cell densities (optical density at $600 \mathrm{~nm}, \mathrm{OD}_{600}$, of 2.49) when it is grown on carbohydrate-restricted MRS broth containing lactococcal cell lysate (Ortakci et al., 2015b). A clear complimentary pattern was observed in the trend lines of growth of $L b$. wasatchensis matching a decrease in starter streptococci numbers (Figure 2). We postulated that free galactose remaining in cheese after lactose fermentation by $S$. thermophilus and ribose released via its subsequent lysis enables co-utilization of both sugars by $L b$. wasatchensis in a manner that maximizes its rate and extent of growth (Ortakci et al., 2015a). Slower growth of $L b$. wasatchensis during the first 8 wk of storage at $6^{\circ} \mathrm{C}$ supports our hypothesis because starter streptococci counts never decreased below $10^{9} \mathrm{cfu} / \mathrm{g}$ during this period, thus providing less cell lysate material with the needed pentose to support growth of Lb. wasatchensis.

\section{Relative Gas and Splits in Cheese}

The largest amount of gas was produced in cheese with added $L b$. wasatchensis and ripened at $12^{\circ} \mathrm{C}$ (Figure 4). All effects and interactions were significant at $P \leq 0.01$ (Table 2). At $6^{\circ} \mathrm{C}$, cheese with added $L b$. wasatchensis showed no sign of gas formation during 23 wk of storage. An association between elevated storage temperatures and gassy defect in cheese has been reported previously (Elliott et al., 1981; Laleye et al., 1987). Elliott et al. (1981) found that gas formation occurred in cheese stored at $10^{\circ} \mathrm{C}$ but not at $4.5^{\circ} \mathrm{C}$, and within $6 \mathrm{mo}$ in cheese inoculated with a slowgrowing gas-forming bacterium that may be similar to $L b$. wasatchensis. Nonetheless, the observation that $L b$. wasatchensis did not promote gassy defect at $6^{\circ} \mathrm{C}$ is different from our recent research with cheese made using Lc. lactis (Ortakci et al., 2015b), in which addition of Lb. wasatchensis did cause gas production at both 6 and $12^{\circ} \mathrm{C}$. This difference may be an indication that lysis of starter culture cells provides $L b$. wasatchensis with additional hexose sugars for gas production as well as the pentoses needed to promote its growth. Our current work using $S$. thermophilus is in accordance with starter cell lysis promoting growth and gas production. When cheese was ripened at $12^{\circ} \mathrm{C}$, a rapid decrease in S. thermophilus numbers occurred, with $\sim 99 \%$ of the cells being lysed within 2 wk (streptococcal numbers drop from $10^{9} \mathrm{cfu} / \mathrm{g}$ to an estimated $10^{7} \mathrm{cfu} / \mathrm{g}$ ), whereas at $6^{\circ} \mathrm{C}$ only about one-third of the cells appear to had been lysed within the first $2 \mathrm{wk}$ of cheese storage (Figure 1).
Although most of the growth of $L b$. wasatchensis and the die-off of starter bacteria occurred during the first 8 wk of storage, blowing of packs was not observed until after this time and only at the elevated storage temperature (Figure 4). This may be a result of needing to have most of the available ribose consumed before extensive production of $\mathrm{CO}_{2}$ occurs, or it may be related to the solubility of $\mathrm{CO}_{2}$ in cheese at $6^{\circ} \mathrm{C}$ (Ortakci et al., 2015b). We know that galactose utilization by $L b$. wasatchensis is considerably slower when no ribose is present (Ortakci et al., 2015a), and, as also shown by Axelsson (2004), fermentation of a hexose, such as galactose, as an energy source is needed for $\mathrm{CO}_{2}$ production by OHF lactic acid bacteria. In the presence of both ribose and galactose, however, Lb. wasatchensis can rapidly use ribose to generate ATP for the cell, whereas the biochemical pathways are available to simultaneously use galactose to provide peptidoglycan precursors for cell wall synthesis and cell growth. Then, when the supply of ribose is exhausted, the cell switches to fermentation of galactose for energy so gas production is observed. This has been noticed when $L b$. wasatchensis was grown in carbohydrate-restricted MRS broth supplemented with ribose and galactose and gas production occurred toward the end of the exponential growth phase and in cheese supplemented with both ribose and galactose (Ortakci et al., 2015a,b).

We postulated that insufficient gas production to loosen packages at $6^{\circ} \mathrm{C}$ is probably a combination of having $1 \log$ less $L b$. wasatchensis than at $12^{\circ} \mathrm{C}$, as well as the increased solubility of $\mathrm{CO}_{2}$ at the lower storage temperature (CRC, 2009). Having slightly higher moisture $(41.5 \%)$ in the cheeses in our study compared

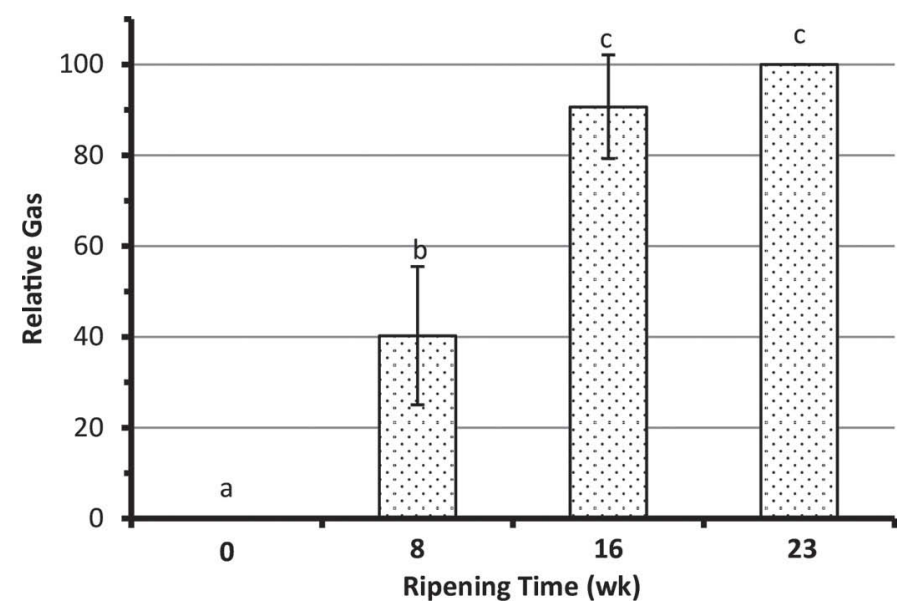

Figure 4. Relative gas formation in Cheddar-style cheese made using Streptococcus thermophilus inoculated with Lactobacillus wasatchensis added at $10^{4} \mathrm{cfu} / \mathrm{mL}$ of milk. Bars $=\mathrm{SE}(\mathrm{n}=3)$. Means with the same letter $(\mathrm{a}-\mathrm{c})$ were not significantly different, $\alpha=0.05$. 

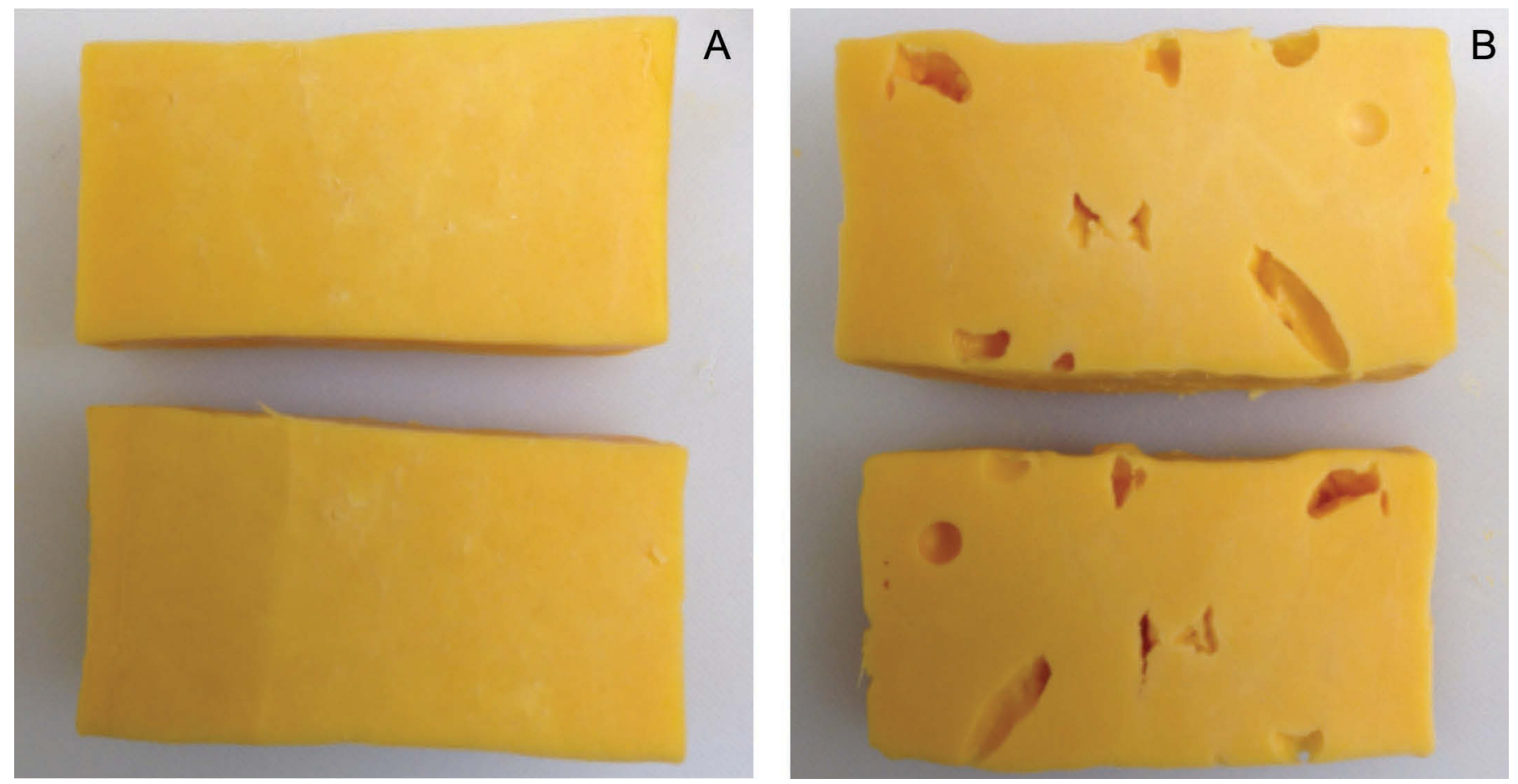

Figure 5. Textural differences after 16 wk of storage at $12^{\circ} \mathrm{C}$ in $(\mathrm{A})$ control cheese or $(\mathrm{B})$ cheese containing inoculated Lactobacillus wasatchensis added at $10^{4} \mathrm{cfu} / \mathrm{mL}$ of milk. Color version available online.

with $37 \%$ in a previous study (Ortakci et al., 2015b) may also be a factor, as higher $\mathrm{CO}_{2}$ levels would be required to saturate the water portion of the cheese before the $\mathrm{CO}_{2}$ is released to loosen the package. Having no gas production in the control cheese stored at $12^{\circ} \mathrm{C}$ was unexpected, as it had been observed previously (Ortakci et al., 2015b). Perhaps insufficient growth of the indigenous $L b$. wasatchensis present in the cheese occurred, but these could not be enumerated against the high level of fast-growing NSLAB in the cheese.

Cheese having higher moisture levels in the current study probably accelerated the occurrence of late gas defects, including the development of irregular shaped voids and round eyes in gassy cheese that had been supplemented with Lb. wasatchensis (Figure 5). Such defective cheese would not be suitable for sale in supermarkets, leading to consumer rejection and avoidance of purchase. In addition, cutting losses of up to $50 \%$ for cheese with slits and cracks is a major economic concern for cheese manufacturers (Golnazarian, 2001).

In large-scale dairy processing, wild-type $S$. thermophilus are often found in pasteurized cheese milk (Hup and Stadhouders, 1979; Bouman et al., 1982; Martley and Crow, 1993). As Martley and Michel (2001) reported, if $S$. thermophilus is present in pasteurized milk at levels sufficient to increase the acid production rate during Cheddar cheesemaking without the cheesemaker's knowledge, the usual response to slow the acid production rate would be to increase the cook temperature or to reduce the amount of starter lactococci (i.e., mesophilic starter culture) used in later vats. However, both approaches unknowingly increase the growth and acid production by $S$. thermophilus over that of starter lactococci (Michel and Martley, 2001). Thus, galactose accumulation would be enhanced under these conditions and, if an OHF NSLAB such as $L b$. wasatchensis is present as part of the resident NSLAB population, this sugar could stimulate its growth and lead to defects with late gas production. Deliberate use of $S$. thermophilus as a starter culture can increase the risk of this problem occurring, and this should be considered when using this strategy to shorten make times for Cheddar cheese. Similarly, using elevated temperatures to shorten the storage time for cheese ripening also increases the risk of having gassy defects develop in the cheese.

\section{CONCLUSIONS}

This study examined consequences of having an $\mathrm{OHF}$ bacteria as part of the background nonstarter microbiota of Cheddar cheese on late gas production when the 
starter culture contains $S$. thermophilus and when the cheese is ripened at elevated temperatures. Milk was deliberately inoculated with $L b$. wasatchensis, a slowgrowing OHF NSLAB species, Cheddar-style cheese was made using an $S$. thermophilus culture, and gas formation was monitored during aging at regular and elevated storage temperatures. Lactobacillus wasatchensis was able to grow $(\sim 3 \log )$ and produced gas after $8 \mathrm{wk}$ at the elevated storage temperature $\left(12^{\circ} \mathrm{C}\right)$. However, at the lower storage temperature $\left(6^{\circ} \mathrm{C}\right)$ no gassiness was observed in the cheese containing added $L b$. wasatchensis, probably because of lower growth (1-log lower counts) during storage. Also, the control cheese did not exhibit any sign of gas formation after $23 \mathrm{wk}$ of storage at either temperature. Utilization of $S$. thermophilus as part of a starter for Cheddar cheese when Lb. wasatchensis (or similar bacteria) is present as a NSLAB should be avoided, especially if a manufacturer is using higher than normal storage temperatures. We conclude that $L b$. wasatchensis is a contributor to late gas production (late blowing) in Cheddar cheese and has previously been undetected because of inherent difficulties in its enumeration because (1) it is slow growing, (2) it requires ribose to grow and form colonies, and (3) its optimum growth temperature is lower than that used in common methods to detect NSLAB in cheese.

\section{ACKNOWLEDGMENTS}

The use of trade names in this publication does not imply endorsement by Utah State University of the products named or criticism of similar ones not mentioned. We thank Bioenergy Life Science Inc. (Ham Lake, MN) for donation of ribose. This research was supported by the National Dairy Council (Rosemont, IL) as part of the cheese applications program at the Western Dairy Center and by the Utah Agricultural Experiment Station, Utah State University, and is approved as journal paper No. 8774 .

\section{REFERENCES}

Agarwal, S., D. McCoy, W. Graves, P. D. Gerard, and S. Clark. 2011. Sodium content in retail Cheddar, Mozzarella, and process cheeses varies considerably in the United States. J. Dairy Sci. 94:16051615.

Axelsson, L. T. 2004. Lactic acid bacteria: Classification and physiology. Pages 1-63 in Lactic Acid Bacteria. S. Salminen and A. von Wright, ed. Marcel Dekker, New York, NY.

Bley, M. E., M. E. Johnson, and N. F. Olson. 1985. Factors affecting nonenzymatic browning of process cheese. J. Dairy Sci. 68:555-561.

Bouman, S., D. B. Lund, F. M. Driessen, and D. G. Schmidt. 1982. Growth of thermoresistant streptococci and deposition of milk constituents on plates of heat-exchangers during long operating times. J. Food Prot. 45:806-812.
Bouzas, J., C. A. Kantt, F. Bodyfelt, and J. A. Torres. 1993. Time and temperature influence on chemical aging indicators for a commercial Cheddar cheese. J. Food Sci. 58:1307-1313.

Broadbent, J. R., C. Brighton, D. J. McMahon, N. Farkye, M. Johnson, and J. Steele. 2013. Microbiology of Cheddar cheese made with different fat contents using a Lactococcus lactis single-strain starter. J. Dairy Sci. 96:4212-4222.

Cogan, T. 2011. Microbiology of Cheddar cheese. Page 625 in Encyclopedia of Dairy Sciences. Vol. 1, 2nd ed. J. W. Fuquay, P. F. Fox, and P. L. H. McSweeney, ed. Academic Press, London, UK.

CRC. 2009. CRC Handbook of Chemistry and Physics: A Ready-Reference Book of Chemical and Physical Data. 90th ed. CRC Press, Boca Raton, FL.

Elliott, J. A., G. E. Millard, and R. A. Holley. 1981. Late gas defect in Cheddar cheese caused by an unusual bacterium. J. Dairy Sci. 64:2278-2283.

Fox, P. F., P. L. H. McSweeney, and C. M. Lynch. 1998. Significance of non-starter lactic acid bacteria in Cheddar cheese. Aust. J. Dairy Technol. 53:83-89.

Golnazarian, C. 2001. Slit formation in Cheddar cheese: A comprehensive investigation of the microbiological parameters associated with this defect. PhD Thesis. University of Vermont, Burlington.

Hup, G., and J. Stadhouders. 1979. Growth of thermoresistant streptococci in cheese milk pasteurizers. 3. Specific bacterial flora and its effect on cheese quality. Zuivelzicht 71:1141-1143.

Hutkins, R. W., and H. A. Morris. 1987. Carbohydrate metabolism by Streptococcus thermophilus: A review. J. Food Prot. 50:876-884.

Hutkins, R. W., and C. Ponne. 1991. Lactose uptake driven by galactose efflux in Streptococcus thermophilus: Evidence for a galactoselactose antiporter. Appl. Environ. Microbiol. 57:941-944.

Laleye, L. C., R. E. Simard, B. H. Lee, R. A. Holley, and R. N. Giroux. 1987. Involvement of heterofermentative lactobacilli in development of open texture in cheeses. J. Food Prot. 50:1009-1012.

Martley, F. G., and V. L. Crow. 1993. Interactions between non-starter microorganisms during cheese manufacture and ripening. Int. Dairy J. 3:461-483.

Martley, F. G., and V. Michel. 2001. Pinkish colouration in Cheddar cheese-description and factors contributing to its formation. J. Dairy Res. 68:327-332.

McMahon, D. J., C. J. Oberg, M. A. Drake, N. Farkye, L. V. Moyes, M. R. Arnold, B. Ganesan, J. Steele, and J. R. Broadbent. 2014 Impact of sodium, potassium, magnesium, and calcium salt cations on $\mathrm{pH}$, proteolysis, organic acids, and microbial populations during storage of full fat Cheddar cheese. J. Dairy Sci. 97:4780-4798.

McSweeney, P. L. H., and P. F. Fox. 2004. Metabolism of residual lactose and of lactate and citrate. Pages 361-372 in Cheese: Chemistry, Physics and Microbiology. Vol 1: General Aspects. 3rd ed. P. F. Fox, P. L. H. McSweeney, T. M. Cogan, and T. P. Guinee, ed. Elsevier, London, UK.

Michel, V., and F. G. Martley. 2001. Streptococcus thermophilus in Cheddar cheese-Production and fate of galactose. J. Dairy Res. $68: 317-325$

Mora, D., M. G. Fortina, C. Parini, G. Ricci, G. Giraffa, and P. L. Manachini. 2002. Genetic diversity and technological properties of Streptococcus thermophilus strains isolated from dairy products. J. Appl. Microbiol. 93:278-287.

Oberg, C. J., L. V. Moyes, M. J. Domek, C. F. Brothersen, and D. J. McMahon. 2011. Survival of probiotic adjunct cultures in cheese and challenges in their enumeration using selective media. J. Dairy Sci. 94:2220-2230.

Oberg, C. J., T. S. Oberg, M. D. Culumber, F. Ortakci, J. R. Broadbent, and D. J. McMahon. 2015. Lactobacillus wasatchensis sp. nov., a non-starter lactic acid bacteria isolated from aged Cheddar cheese. Int. J. Syst. Evol. Microbiol. (Accepted for publication).

Ortakci, F., J. R. Broadbent, C. J. Oberg, and D. J. McMahon. 2015a. Growth and gas production of a novel obligatory heterofermentative Cheddar cheese nonstarter lactobacilli species on ribose and galactose. J. Dairy Sci. 98:3645-3654.

Ortakci, F., J. R. Broadbent, C. J. Oberg, and D. J. McMahon. 2015b. Late blowing of Cheddar cheese induced by accelerated ripening 
and ribose and galactose supplementation in presence of a novel obligatory heterofermentative nonstarter lactobacilli species. J. Dairy Sci. 98:7460-7472. http://dx.doi.org/10.3168/jds.2015-9468.

Peterson, S. D., and R. T. Marshall. 1990. Nonstarter lactobacilli in Cheddar cheese: A review. J. Dairy Sci. 73:1395-1410.

Phadungath, C. 2011. The efficacy of sodium gluconate as a calcium lactate crystal inhibitor in cheddar cheese. PhD Thesis. South Dakota State University, Brookings.

Radford, D. R., and R. R. Hull. 1982. Utilization of carbohydrate in "short method" Cheddar cheese by mesophilic starters. Aust. J. Dairy Technol. 37:104-106.

St-Gelais, D., G. Doyon, J. R. Rolland, and J. Goulet. 1991. Sugar and organic acid concentrations during ripening of Cheddar cheese-like products. Milchwissenschaft 46:288-291.

Tabasco, R., T. Paarup, C. Janer, C. Peláez, and T. Requena. 2007. Selective enumeration and identification of mixed cultures of Streptococcus thermophilus, Lactobacillus delbrueckii ssp. bulgaricus, L. acidophilus, L. paracasei ssp. paracasei and Bifidobacterium lactis in fermented milk. Int. Dairy J. 17:1107-1114.

Tinson, W., A. J. Hillier, and G. R. Jago. 1982a. Metabolism of Streptococcus thermophilus. 1. Utilization of lactose, glucose and galactose. Aust. J. Dairy Technol. 37:8-13.
Tinson, W., M. F. Ratcliff, A. J. Hillier, and G. R. Jago. 1982b. Metabolism of Streptococcus thermophilus. 3. Influence on the level of bacterial metabolites in Cheddar cheese. Aust. J. Dairy Technol. $37: 17-21$.

Upreti, P., L. E. Metzger, and K. D. Hayes. 2006b. Influence of calcium and phosphorus, lactose, and salt-to-moisture ratio on Cheddar cheese quality: Proteolysis during ripening. J. Dairy Sci. 89:444-453.

Upreti, P., L. L. McKay, and L. E. Metzger. 2006a. Influence of calcium and phosphorus, lactose, and salt-to-moisture ratio on Cheddar cheese quality: changes in residual sugars and water-soluble organic acids during ripening. J. Dairy Sci. 89:429-443.

Vaillancourt, K., J. D. LeMay, M. Lamoureux, M. Frenette, S. Moineau, and C. Vadeboncoeur. 2004. Characterization of a galactokinasepositive recombinant strain of Streptococcus thermophilus. Appl. Environ. Microbiol. 70:4596-4603.

Wehr, H. M., and J. F. Frank. 2004. Standard Methods for the Examination of Dairy Products. 17th ed. American Public Health Association, Washington, DC. 